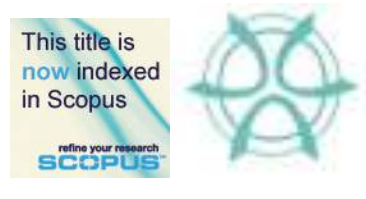

PLANNING MALAYSIA:

Journal of the Malaysian Institute of Planners

SPECIAL ISSUE IV (2016), Page 251 - 262

\title{
MANGROVES DEGRADATION: A LOCAL PERSPECTIVE ON ITS AWARENESS
}

\author{
Mazni Adibah Abd Rahman ${ }^{1} \&$ M.Zainora Asmawi \\ ${ }^{1,2}$ Kulliyyah of Architecture \& Environmental Design \\ INTERNATIONAL ISLAMIC UNIVERSITY MALAYSIA
}

\begin{abstract}
Mangroves in Malaysia reside on the coastlines, and the largest areas of mangrove are in the Northern Sabah. Over the past decades, mangrove species have been reported to be disappearing from the globe. It is due to several natural processes that have been inserted to fill the needs of the increased population. These include illegal logging, agriculture activities and urbanisation. In this regards, awareness of the local residents about the problem of mangrove depletion is important to inhibit the problem to prolong further.Therefore, this research was conducted to determine the degree of awareness of local residents on the importance of mangroves in managing environmental quality. Consequently, a questionnaire survey was conducted on 103 respondents to examine their awareness on the subject of mangrove degradation.The respondents were selected randomly among local residents of Kuala Selangor district.It is found that only twenty percent of the total number of respondents are totallyaware of the issue and acted upon it; either taking part in the endeavours made by the government as well as those with the non-governmental bodies or practicing mangroves replanting at their backyard.
\end{abstract}

Keyword: Mangroves; Local Residents; Degradation; Awareness

\section{INTRODUCTION}

Mangroves has been long recognized as one of an efficient tool in managing the environmental quality. Its contribution is widely accepted in the sectors linked to social, economic and physical dimensions. It is a devastating situation where the natural environment is sacrificed in meeting the demands of 6.0 billion of people on the planet (Valeila et al., 2009). Permanent Reserve Forest, cutting through the mangrove ecosystem is an asset to the state and contributed to the nations' economy, biodiversity, and the environment. Granting to the Food and Agriculture Organization (FAO) in 1980, mangrove forests are recorded to be 674,000 ha in Malaysia (FAO, 2007). Still, interpretations are changing in the succeeding ten years with a decreasing of 0.5 percent, with only 642,000 ha in 1990 (FAO, 2007). Eventually, the record of 2005, Malaysia has only 565,000 ha of mangrove woods, with decreasing 1.62 percent (FAO, 2007). Selangor has the highest total loss of mangrove area for the past two decades, from 1990-2010 (Refer table 1). Furthermore, according to Kamariah et al., (2014), compared to the world's land-based forests, destruction of the mangrove ecosystem went four times faster 
Mazni Adibah Abd Rahman \& M.Zainora Asmawi

Mangroves Degradation: A Local Perspective on its Awareness

and one-twenty percent of the world's mangrove was lost since 1980; at 35,500 square kilometres.

Table 1: The changes of mangrove areas in the last two decades

\begin{tabular}{lccccc}
\hline State & $\begin{array}{c}\text { Mangrove } \\
\text { area (ha) } \\
\mathbf{1 9 9 0}\end{array}$ & $\begin{array}{c}\text { Mangrove } \\
\text { area (ha) }\end{array}$ & $\begin{array}{c}\text { Mangrove } \\
\text { area (ha) } \\
\mathbf{2 0 0 0}\end{array}$ & $\begin{array}{c}\text { Mangrove } \\
\text { loss (ha) } \\
\mathbf{1 9 9 0 - 2 0 1 0}\end{array}$ & $\begin{array}{c}\text { Mangrove } \\
\text { loss (\%) } \\
\mathbf{1 9 9 0 - 2 0 1 0}\end{array}$ \\
\hline Johor & $29,797.13$ & $25,477.19$ & $23,6767.43$ & 61020.70 & 20.54 \\
Kedah & $9,236.24$ & $8,322.79$ & 7841.25 & 1394.99 & 15.10 \\
Pahang & $11,467.03$ & $10,791.42$ & 9039.26 & 2427.77 & 21.17 \\
Perak & $52,562.00$ & $46,057.00$ & 43291.97 & 9270.03 & 17.64 \\
Selangor & $28,954.60$ & $24,213.14$ & 22530.20 & 6424.40 & 22.19 \\
Total & $\mathbf{1 3 2 , 0 1 7 . 0 0}$ & $\mathbf{1 1 4 , 8 6 1 . 5 4}$ & $\mathbf{1 0 6 3 7 9 . 1 1}$ & $\mathbf{2 5 6 3 7 . 8 9}$ & $\mathbf{1 9 . 4 2}$ \\
\hline
\end{tabular}

Source: Hamdan et al., 2010 in FRIM, 2012.

Awareness of the residents determines the effectiveness of rehabilitation programs done by either the Government or the Non-Government organization. A good and successful environment management depends on the awareness that depicted perfectly in accommodating the issues and problem while rehabilitation programs are well implemented and enforced. Therefore, it is the argument of this research that there is not enough awareness in some of the residents, and the lack of this awareness is because poor participation in mangrove rehabilitation programs.

\section{METHODOLOGY}

Information collection included in this work includes primary and secondary information. Primary data gathered in this study are through a conducted face-to-face questionnaire survey. The queries included in the survey are open and closed questions mainly on the knowledge of mangrove awareness of the field. The respondents are limited (sampling size is 103) to the local residents of Kuala Selangor. The designed questionnaire is to measure the level of awareness regarding mangrove loss due to several activities ongoing in the mukim.

The questionnaire consists of three parts. The first part is the respondents particular details. Part 2 is their general opinion on mangrove forest, and part three assesses their opinion on the mangrove degradation issue and awareness in Kuala Selangor

\section{MANGROVE AND ITS ECOSYSTEM}

Malaysia in one of the states ratified the RAMSAR convention in 1994. RAMSAR convention defined wetlands as areas of marsh, fen, peatland or water, whether natural or artificial, brackish or salt, including areas of marine water the depth of which at low tide does not exceed six meters (Article 1.1 of the Convention) (Ramsar Convention Secretariat [RCC], 2013). According to Britannica Concise Encyclopedia, "Mangrove" is defined as any or certain shrubs and trees that belong to the families Rhizophoraceae, Acanthaceae, Lythraceae, Combretaceae, and Arecaceae (Palmae). It originates in the dense thickets or forest on the tidal estuaries, in salt marshes and on muddy coasts (Encyclopædia Britannica, Inc., 2015). 
There has been an explosion of scientific research on mangrove biological and ecological aspects. Nevertheless, issues among local community restoration planning are limited (Davenport et al., 2010 in Kamariah et al., 2014). Rather, most studies concentrate on the statistics of Malaysia's mangrove protected area, mangrove ecosystem and its' biodiversity, management aspects, status and trends, values and depleting reasons such as Field (1998), Kamaruzaman et. al. (2008), FAO (2007), Macintosh et. al. (2002) and Kathiresan (2012).

In fact, awareness on this issue has been increasing recently and has led more efforts and actions in protecting the ecosystem. Either local authorities or international commitment organizations organize rehabilitation and restoration programs. Rehabilitation is an act of getting the ecosystem back into its original condition through many means (Field, 1996 in Macintosh et. al., 2002). In restoring the system, there are numbers of action, which helps the ecosystem to heal.

"Community-based conservation" or CBC concept is apply to many conservation projects that relate to the significant characteristics of community participation, including community-based natural resource management, community-based social-ecological systems approaches, community-based conservation-protected area, incentive-based conservation and ecosystem management and others (Gruber, 2010 in Kamariah, 2014). Therefore, CBC is a conservation effort by and for communities, with active partners in protected area management (Kamariah et. al., 2014).

\section{FUNCTION OF MANGROVES}

Humans in earlier history use mangroves as firewood, charcoal, timber poles and in fish trap construction (FAO, 2007). Mangroves are acknowledged for their "direct" and "indirect" functions (Choudhury, n.d). Direct functions of mangroves include as construction wood, board and rayon mills, in tanning industry, charcoal, timber poles and several edible products - i.e.,; honey, fruits and meat (FRIM, 2012).

Indirectly, mangrove forests have the capacity to fight on the shock of the cyclone and tidal surges (FRIM, 2012).Mangrove forest is recognized to supply habitat for a diverse group of fauna. It is the spawning ground for fish and crustacean family. Mangrove forests also protect our coastlines from the tsunami, as they are the first nature belt of the coastal (FRIM, 2012; Iwan Tri Cahyo et. al., 2006).

\section{VALUES OF MANGROVES}

Mangrove forest supports the economic activities (FRIM, 2012; Malaysia Timber Council [MTC], 2009), through nutrient recycling, water purification and flood control (FRIM, 2012). In assessing value of mangrove, it can then be divided into three values; the community, economic and ecological values.

\section{Economic Value}

Coastal areas are the centre of attraction for the tourist. Therefore, maintaining the coastal is necessary. Mangrove ecosystem is a natural buffer zone to the water system in coastal protection. Mangrove forest could reduce the erosion along the coastlines by barricading and slowing down the waves (FRIM, 2012). However, if the ecosystem is managed incorrectly, clearance of mangroves results in shoreline erosion. A chemical reaction occurs when acid sulphate soils are exposed to oxygen due to erosion and shallow of 
Mazni Adibah Abd Rahman \& M.Zainora Asmawi

Mangroves Degradation: A Local Perspective on its Awareness

estuaries, sulfuric acid may produce. In time, coastal erosion harms the economic activities as well.

In commercial fishing, the mangrove forest is recorded to contribute million Ringgit Malaysia to the nations' economy (FRIM, 2012; MTC, 2009). Perak has recorded the highest contribution to the country's economy through commercial fishing, charcoal, poles and shingles industries (Department of Fisheries, 2013) (Refer table 2). Economically, mangrove forest has taken commercial fishing to a new level.

Besides that, mangrove forest contributed to the charcoal and poles industry. In Malaysia, charcoal, shingles, and poles industry contributes significantly to the country's economy (MTC, 2009; FRIM, 2012). Different types of mangrove trees carry different characteristics. Thus, several mangroves usage are listed out accordingly (Refer table 3).

Table 2: Landing of marine fish by state in Peninsula Malaysia in year 2009

\begin{tabular}{lc|c}
\hline State & \multicolumn{2}{c}{ Fish Catches } \\
\hline West Coast & Metric tons & Value (RM) \\
\cline { 2 - 3 } Perlis & 178,247 & $805,640,168$ \\
Kedah & 106,486 & $614,680,958$ \\
Pulau Pinang & 42,790 & $254,041,412$ \\
Perak & 258,086 & $1,155,477,524$ \\
Selangor & 131,350 & $471,556,535$ \\
Negeri Sembilan & 610 & $7,731,460$ \\
Melaka & 1,691 & $18,054,463$ \\
West Johor & 10,298 & $65,968,951$ \\
\hline Total & 729,558 & $3,393,151,472$ \\
\hline East Coast & & $238,679,360$ \\
Kelantan & 58,891 & $445,703,808$ \\
Terengganu & 84,319 & $603,152,352$ \\
Pahang & 115,955 & $324,453,770$ \\
East Johor & 77,316 & $1,611,989,291$ \\
\hline Total & 336,512 & $5,005,140,762$ \\
\hline Peninsula Malaysia & $1,066,069$ & \\
\hline
\end{tabular}

Source: Department of Fisheries 2013, http://www.dof.gov.my/en/fishery-statistics 
Table 3: Timber quality and uses of mangrove trees

\begin{tabular}{|c|c|c|}
\hline Mangrove Species & Characteristics of the timber & Prevailing \\
\hline Avicennia spp. & $\begin{array}{l}\text { Hard and heavy wood, difficult } \\
\text { to saw. }\end{array}$ & $\begin{array}{l}\text { Rarely used for charcoal, } \\
\text { Chip wood and panels, poor } \\
\text { fuelwood. }\end{array}$ \\
\hline $\begin{array}{l}\text { Bruguiera } \\
\text { parviflora }\end{array}$ & Hard reddish wood. & $\begin{array}{l}\text { Pits prop, construction } \\
\text { scaffoldings. }\end{array}$ \\
\hline Rhizophora spp. & $\begin{array}{l}\text { Heavy, dark red wood, silvery } \\
\text { grain in radial cuts, fresh wood } \\
\text { of short durability, needs long } \\
\text { drying. }\end{array}$ & $\begin{array}{l}\text { Construction, rail ties panels; } \\
\text { fishing rods, root system for } \\
\text { spiritual carvings, fibers, } \\
\text { fuelwood and charcoal } \\
\text { production. }\end{array}$ \\
\hline Sonneratia alba & $\begin{array}{l}\text { Hardwood, resistant to } \\
\text { shipworm that corrodes the } \\
\text { plank. }\end{array}$ & $\begin{array}{l}\text { Poor fuelwood, poles for } \\
\text { houses, bridges, well, boats } \\
\text { coppices for fences. }\end{array}$ \\
\hline
\end{tabular}

Source: Tomlinson, 1995 and MNS, 2010 in FRIM, 2012

Likewise, to the ceremonious use of mangrove tree, with the research and growth lead by FRIM, value-added mangrove products are produced; such as high quality indoor and outside furniture (FRIM, 2012). Furthermore, a sound business strategy could introduce timber products to higher values and in international markets.

\section{Community Value}

The broader community today has come to appreciate the mangrove ecosystem. In one occasion, visitors appreciate nature while enjoying the ecosystem in separate recreation activities. For instance, finding satisfaction in bird watching, bird lovers appreciate the mangroves for it attracts and support varied species of rare birds (FRIM, 2012). As mangroves provide the breeding ground for rare fish, recreational fishers highly rely upon the mangrove forest for leisure pursuits (FRIM, 2012). In addition, mud crabs and shrimps are normally set up in the region.

Students gain knowledge on the natural environment through mangrove forest as it backs up the planetary food chain. Furthermore, currently ecotourism and wildlife education are growing sectors calling many locals, the foreign tourist, schools and environmentalist (FRIM, 2012).

\section{Ecological Value}

Mangrove forests support a massive range of flora includes palms, shrubs and ferns (FRIM, 2012). In fact, these plants suit well with the ecosystem. The ecosystem, not only provides a breeding ground to many marine lives, it also contributed in sustaining fish and crustacean populations (FRIM, 2012). Besides that, the mangroves support the wildlife of crocodile, birds, tigers, deer, monkeys and honeybees.

Mangrove productivity is significant because it bears a direct impingement on the health and function of the marine food chain (FRIM, 2012).The concept of productivity mentioned is to depict the ecological value and part of the ecosystem. In general, high levels of productivity supports diverse animal within the ecosystem. Measuring the productivity level is hard and the results may not in absolute term. However, it is likely 
Mazni Adibah Abd Rahman \& M.Zainora Asmawi

Mangroves Degradation: A Local Perspective on its Awareness

to calculate its changes in certain elements of mangrove ecosystem that later used as a guide towards efficiency (FRIM, 2012). Furthermore, mangrove forest plays a vital role in shoreline protection, by reducing erosion and the impact of strong winds (FRIM, 2012; Kathiresan, 2012).

\section{MANGROVES IN SELANGOR}

Selangor has a large extent of mangrove forest (Refer figures $1 \& 2$ ). Selangor is situated in the west region of the peninsula and has about 90-kilometre length of coastlines from Sungai Bernam to Sungai Sepang in the south (Kamaruzaman et. al., 2008). It is also surrounded by big islands along the coast (FRIM, 2012). According to Ong (1991), 60 per cent of the coastlines are covered with mangroves (Ong et. al., 1991 in FRIM, 2012). The total area of mangrove forests in Selangor is 22,530.20 hectares; with the highest distribution in Klang with 16,630.87 hectares (Forestry Department Peninsular Malaysia, 2010 in FRIM, 2012) (Refer figure 2). Since 1962, mangrove forests in Selangor have been managed under a proper management-working plan for the production of poles industries and areas for conservation and protection (FRIM, 2012).

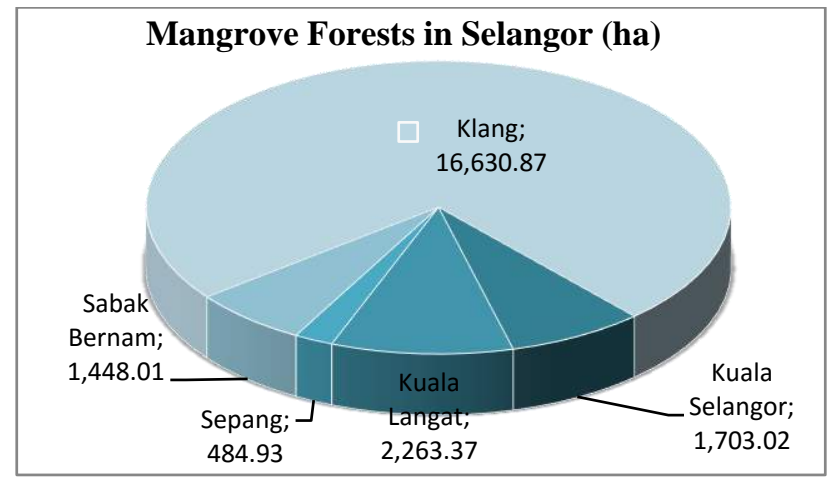

Figure 1: Mangrove forests in Selangor as of December, 2010 Source: FRIM, 2012. 


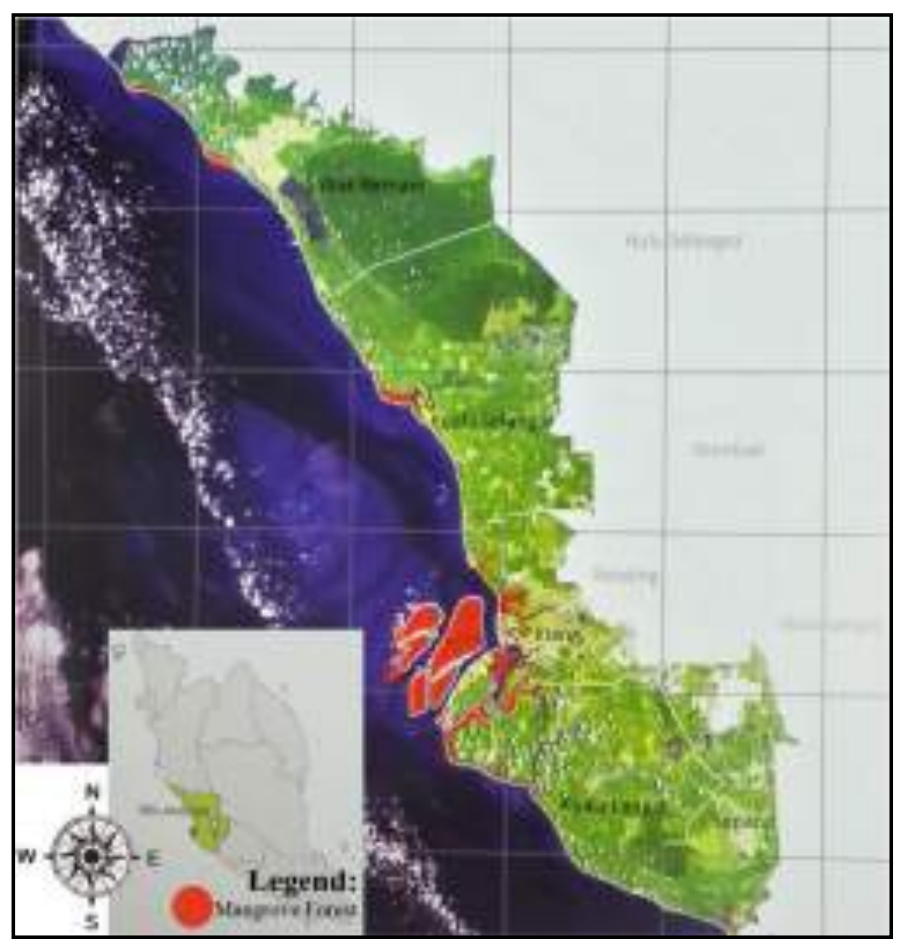

Figure 2: Distribution map of mangroves in Selangor by December 2012 Source: Forestry department Selangor in FRIM, 2012.

\section{STUDY AREA: KUALA SELANGOR, SELANGOR MALAYSIA}

Kuala Selangor is located 64 kilometres north of Kuala Lumpur city centre. Kuala Selangor is bordered Klang and Petaling in the south, Gombak and Hulu Selangor district in the east and Sabak Bernam in the north (Refer figure 3). The overall area of Kuala Selangor is 119,452.46 hectares, which include nine mukims, which are; Kuala Selangor, Hujong Permatang, Pasangan, Ijok, Batang Berjuntai, Api-Api, Tanjong Karang, Jeram, and Hulu Tinggi (KSDC, 2014).

Kuala Selangor main development mission is to develop the district as an eco, agro and cultural heritage tourism based district in the state of Selangor (KSDC, 2014). Supporting this vision, the district council has formulated several objectives. Among the listed objectives, one related to mangrove forest is to maintain and preserve the ecology balance and sustainability of the natural environment with the protection of the Environmental Sensitive Area (ESA) in Kuala Selangor (KSDC, 2014). 
Mazni Adibah Abd Rahman \& M.Zainora Asmawi

Mangroves Degradation: A Local Perspective on its Awareness

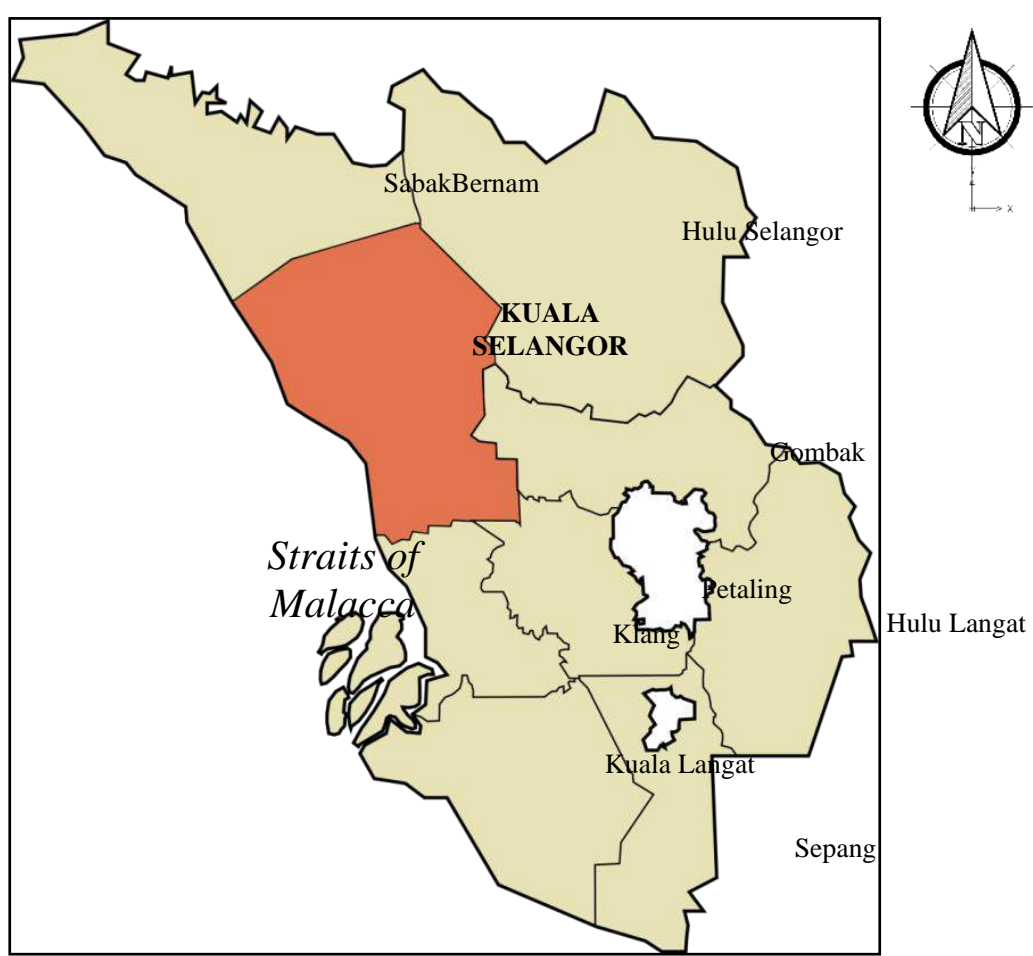

Figure 3: Map of districts in Selangor

Source: Amended from Kuala Selangor District Council, 2014.

http://kualaselangor.selangor.gov.my/kualaselangor.php/pages/view/103

\section{FINDINGS OF STUDY}

In the final section of the survey, respondents were asked several questions about their awareness on the issue of mangrove degradation, the reason of mangrove depletion, medium encounter the issue and the responsible body in managing with mangrove forest. The results show that 20 per cent that is totally aware perfectly of the issue; what happen, where did it took place and who is responsible in the matter (Refer table 4). Following to the number is the "Moderate Awareness" group with 36 respondents at 35 percentile. Wong (2006) says that the increasing level of awareness of the local community is the first step in empowering the local participation in planning and managing their natural resources. In the context of Kuala Selangor, it appears that there is potential future for better support to manage the mangrove regions. 
Table 4: Awareness of the mangrove forest degradation issue in Kuala Selangor

\begin{tabular}{|l|c|c|c|}
\hline Awareness & Frequency & Percent & Cumulative percent \\
\hline Totally Aware & 20 & 20 & 20 \\
\hline Moderate Awareness & 36 & 35 & 55 \\
\hline Weak Awareness & 23 & 22 & 77 \\
\hline Not Aware & 24 & 23 & 100 \\
\hline Total & $\mathbf{1 0 3}$ & $\mathbf{1 0 0}$ & - \\
\hline
\end{tabular}

The next question asked to the respondents is; from what media or medium they encounter this issue. This is an open answer question where the respondent is to choose more than one choice of the given option. This has resulted in 51 respondents choosing the option "Television" and 49 respondents choose "Newspapers" (Refer table 5) and thus carry 23.8 per cent and 22.9 per cent respectively.

Table 5: Medium respondent encounter the issue of mangrove degradation from

\begin{tabular}{llcc}
\hline \multirow{2}{*}{ Medium } & & \multicolumn{2}{c}{ Responses } \\
\cline { 3 - 4 } & Radio & Number & Percent \\
\cline { 2 - 4 } & Newspaper & 6 & $2.8 \%$ \\
\cline { 2 - 4 } & Television & 59 & $22.9 \%$ \\
\cline { 2 - 4 } & Journal & 15 & $23.8 \%$ \\
\cline { 2 - 4 } & Friends & 34 & $7.0 \%$ \\
\cline { 2 - 4 } & Internet & 36 & $15.9 \%$ \\
\cline { 2 - 4 } & Institution & 16 & $16.8 \%$ \\
\cline { 2 - 4 } & Authority & 7 & $3.5 \%$ \\
\hline Total & & $\mathbf{2 1 4}$ & $\mathbf{1 0 0 . 0 \%}$ \\
\hline
\end{tabular}

Subsequently, they were asked in their opinion on the reasons of mangrove degradation in Kuala Selangor. Most respondents pick "Illegal Logging" as the main factor with 30.4 per cent, while "Urbanization process" is the second reason with 23.7 percentile (Refer table 6). However, a dissimilar result was seen from the reasons listed out by Forest Research Institute Malaysia. The reasons as listed out by FRIM include urbanization, aquaculture, agriculture and coastal erosion; as supported in their research.

Table 6: Reasons of mangrove degradation on the respondents' opinion

\begin{tabular}{lllcc}
\hline \multirow{3}{*}{$\begin{array}{l}\text { Reason } \\
\text { Degradation }\end{array}$} & \multirow{2}{*}{ of } & \multicolumn{2}{c}{ Responses } \\
\cline { 3 - 4 } & Urbanization & Number & Percent \\
\cline { 3 - 4 } & Aquaculture & 46 & 23.7 \\
\cline { 2 - 4 } & Agriculture & 10 & 18.6 \\
\cline { 2 - 4 } & Water Pollution & 43 & 5.2 \\
\cline { 2 - 4 } & Illegal Logging & 59 & 22.2 \\
\hline Total & & $\mathbf{1 9 4}$ & $\mathbf{1 0 0 . 0}$ \\
\hline
\end{tabular}


Mazni Adibah Abd Rahman \& M.Zainora Asmawi

Mangroves Degradation: A Local Perspective on its Awareness

Next question, respondents are asked about the importance of spreading the news of mangrove degradation to all Kuala Selangor residents or not. More than 100 respondents agreed; that educating Kuala Selangor residents are vital towards better understanding the mangrove loss issue. That is 99 percent to 59.2 chooses "Very Important" and 39.8 percent chooses "Important" (Refer figure 4).

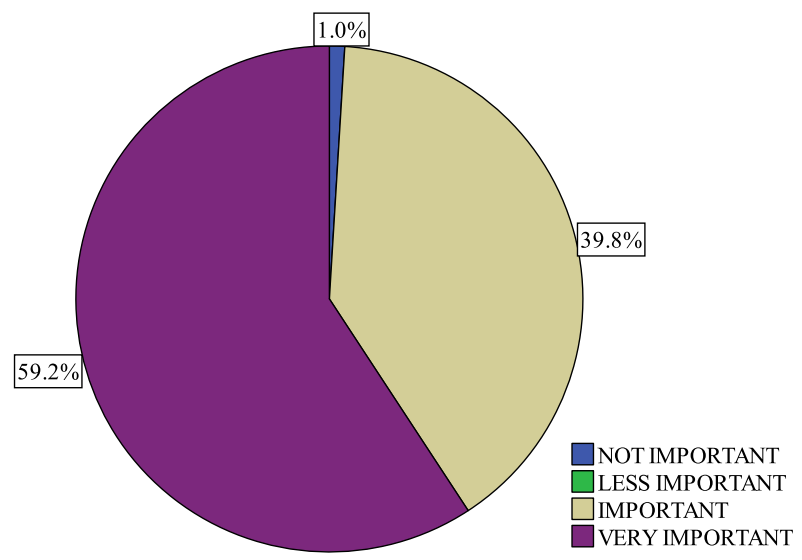

Figure 4: The importance in educating people of Kuala Selangor towards the issue of mangrove depletion

The final question of the survey questioned their choice of who are responsible towards the environment. The options given are among the Government, NonGovernmental Organizations, and the public. Out of those options, the most picked option is the Government with 38.5 percentile, followed by the Public with 36.3 percentile (Refer table 7). A sum of 33 respondents is recorded to select all three agencies as they consider that it is the responsibility of all residents of the country to protect the surroundings. This finding conforms to the view of Irini et. al. (2012) in which they mention about several roles of NGOs in mangrove conservation. 
Table 7: Responsible bodies in taking care of the mangrove forest

\begin{tabular}{llcc}
\hline & & \multicolumn{2}{c}{ Responses } \\
\cline { 3 - 4 } Responsible & & Number & Percent \\
\cline { 2 - 4 } & Public & 66 & 36.3 \\
\cline { 2 - 4 } & Government & 70 & 38.5 \\
\cline { 2 - 4 } & Non-Government & 46 & 25.3 \\
\hline Total & & $\mathbf{1 8 2}$ & $\mathbf{1 0 0 . 0}$ \\
\hline
\end{tabular}

\section{CONCLUSION}

Throughout the study, it has been argued that the awareness level of the local community towards mangrove depletion is still low, yet we are losing mangrove forests at 22 percent for the last two decades. This has been confirmed by FRIM, through their research saying that Selangor has the highest total loss of mangrove area for the past two decades, from 1990-2010. Thus, public understanding and awareness in regards of the mangrove biological and economy values are vital in ensuring the proper management of this resource. The findings of the research indicate the potential of future actions which the local residents can participate in managing their local mangrove habitat. The collaboration of many stakeholders in policy making for a better and effective mangrove management is called for either at the local level or state level. All stakeholders responsible for managing mangroves should play their roles efficiently to ensure that the valuable mangroves are well protected for the sake of future generations.

\section{REFERENCES}

Valiela, I., Kinney, E., Culbertson, J., Peacock, E., \& Smith, S. (2009). Global Loss of Coastal Habitats, Rates, Causes and Consequences, Global Losses of Mangroves and Salt Marshes. In Duarte, C. M. (pp. 109-120). Fundacion BBVA.

Food and Agriculture Organization of the United Nations. (2007). The World's Mangrove 1980-2005 A Thematic Study Prepared in the Framework of the Global Forest Resources Assessment 2005. Rome.

Kamariah, Abdullah; Abdullah, Mohammad Said \& Dasimah, Omar. (2014) Procedia Social \& Behavioral Science, Community-Based Conservation in Managing Mangrove Rehabilitation in Perak \& Selangor, 153, 121-131.

Ramsar Convention Secretariat. (2013). The Ramsar Convention Manual: a guide to the Convention on Wetlands (Ramsar, Iran, 1971), 6th ed. Ramsar Convention Secretariat, Gland Switzerland.

Encyclopædia Britannica, Inc. (2015). Mangrove: plant, Retrieved May 3rd, 2015. http://global.britannica.com /EBchecked/topic/362022/mangrove

Field, C.D. (1998). Marine Pollution Bulletin, Rehabilitation of Mangrove Ecosystem: An Overview, Great Britain, Elsevier Science Ltd., 37 (8-12), 383-392.

Kamaruzaman, Jusoff \& Dahlan, Taha. (March, 2008). Journal of Sustainable Development, Managing Sustainable Mangrove Forests in Peninsular Malaysia., $1(1), 88-96$.

Kathiresan, K. (2012). International Journal of Marine System Science, Importance of Mangrove ecosystem, Vol.2, No10 70-89 (doi: 10.5376/ijms.2012.02.0010) 
Mazni Adibah Abd Rahman \& M.Zainora Asmawi

Mangroves Degradation: A Local Perspective on its Awareness

Macintosh, D.J., Ashton, E.C., \& Havanon, S. (2002). Estuaries, Coastal \& Shelf Science, Mangrove Rehabilitation and Intertidal Biodiversity: A Study in the Ranong Mangrove Ecosystem, Thailand. Estuaries, (55), 331-345.

Forest Research Institute Malaysia. (2012). Status of Mangroves in Peninsular Malaysia (O. Hamdan, Ed.) Malaysia: Gemilang Press Sdn Bhd.

Malaysian Timber Council. (2009, June). Matang Mangroves: A Century of Sustainable Management. Timber Malaysia , 15 (3), pp 6-11.

Kuala Selangor District Council. (2010). Local Plan Kuala Selangor District Counci 2015. Kuala Selangor: MDKS.

Wong, E. (2006). Public Participation in Environmental Planning and the Preparation Process of Local Plans. Paper presented at the Fourth Sabah-Sarawak Environmental Convention.

Choudhury, J. K. (n.d.). Mangroves and Other Coastal Forests, Sustainable Management of Coastal Mangrove Forest Development and Social Needs., 38(6), 267-286.

Iwan Tri Cahyo, W., \& I.Nyoman, S. (2006). Study of Lessons Learned from Mangrove/Coastal Ecosystem Restoration Efforts in Aceh since the Tsunami. Bogor: Wetlands International Indonesia Programme.

Irini, Ibrahim\& Norazlina, Abdul Aziz. (2012). Procedia Social \& Behavioral Science, The roles of international NGOs in the conservation of Bio-Diversity of Wetlands, $40,242-247$. 